\title{
PEHMEÄÄ JA TEKNOLOGISTA OSAAMISTA TULEVAISUUDEN KORKEAKOULUKIRJASTOISSA
}

Työelämän nopea muutos vaikuttaa kirjastotyöhön. Kirjastoissa on paljon uusia tehtäviä, jotka menevät perinteisen kirjastotyön ohi. Muutokset organisaatiossa edellyttävät työntekijöiltä joustavuutta ja valmiutta tarttua uudenlaisiin tehtäviin. Uusien tehtävien myötä kirjastoihin rekrytoidaan muitakin kuin kirjastoammatillisen koulutuksen saaneita työntekijöitä: viestintä- ja järjestelmäosaajia, pedagogeja, tapahtumatuottajia, datanhallintataitoja ja palvelumuotoilijoita. Samalla työelämän muutos on herättänyt tarpeen undistaa koulutusta. Elokuussa 2019 SeAMK kutsui työelämän edustajia sekä SeAMKin Kirjasto- ja tietopalvelualan tutkinto-ohjelman opettajia saman pöydän ääreen keskustelemaan siitä, miten kirjastoalan koulutusta tulisi uudistaa. Tarkastelemme asiaa tässä artikkelissa korkeakoulukirjastojen näkökulmasta, mutta monet asiat ovat yhteisiä kaikille kirjastosektoreille.

Muuttuva työ - muuttuvat kompetenssit

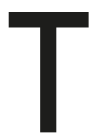
he American Library Assosioation (ALA) identifioi trendikatsauksessaan kirjastojen kannalta relevantteja trendejä, jotka vaikuttavat alan tulevaisuuteen. Trendejä on tarkastelut hyvin laaja-alaisesti huomioiden yhteiskunnallisia, teknologisia, koulutukseen ja ympäristön liittyviä näkökulmia sekä poliittinen päätöksenteko, taloudellinen kehitys, sekä demografiset tekijät. Robotisaatio ja töiden automatisointi vaikuttaa nyt kirjastotyöhön, mutta emme vielä tiedä miten esimerkiksi puheen tunnistamiseen liittyvät teknologiat tulevaisuudessa muuttavat tiedonhaun välineitä.
Tekoälyyn perustuvia sisällönkuvailutyökaluja kehitetään parasta aikaa. Miten virtuaalitodellisuus osana tiedettä ja taidetta muuttaa kirjastoammatillista työtä? Toisaalta teknologisen kehityksen rinnalla kirjaston palveluiden ja erityisesti tilan merkitys yhteisöllisyyden ja yhdessä tekemisen luovana paikkana sekä ärsykevapaana tilana kasvaa. Millaisella osaamisella voimme vastata näihin haasteisiin?

Sandra Hirshin (2019) mukaan kirjaston tulee olla aktiivinen muutoksen edistäjä yhteisössä tai organisaatiossa eikä vain muutoksen omaksuja. Jotta kirjastoammattilaiset olisivat aktiivisia muutoksen tekijöitä, tarvitaan perinteisten alan 
osaamisten lisäksi uusia kirjastotyön kompetensseja, jotka hän jakaa pehmeisiin ja teknologisiin taitoihin.

Pehmeitä taitoja ovat

- kriittinen ajattelu

- yhteistyökyky

- itsenäinen työote

- kyky ajatella luovasti ja positiivisesti

- vuorovaikutustaidot

- ammatillinen verkostoituminen

- johtamiseen ja organisaatioon liittyvät taidot

- innostuminen jatkuvasta oppimisesta ja uusista rooleista.

Teknologisia taitoja ovat

- tietokone- ja internet taidot

- kyky ottaa käyttöön uusia teknologioita: tekoäly, chattibotit, koneoppiminen ja lohkoketjut sekä erilaiset järjestelmät

- tietokantaosaaminen

- tiedonhaku ja sen ohjaaminen verkossa.

Hirshin mukaan kirjastoalan tulevaisuuden koulutuksessa tulee ymmärtää teknologisia, sosiaalisia ja taloudellisia trendejä globaalisti. Lisäksi koulutuksen suunnittelussa tulee pitää tiiviisti yhteyttä työnantajiin, seurata työllistymisen trendejä ja lisätä työelämäkontakteja opintojen aikana. Opiskelijoita tulee saada erilaisista yhteisöistä monipuolisilla taustoilla, jotta voidaan vastata annettuihin odotuksiin.

Yleisen työelämän muutoksen lisäksi kirjastojen osaamistarpeisiin vaikuttaa yleisten kirjastojen osalta myös kirjastolaista tulevat velvoitteet. Korkeakoulu- ja erikoiskirjastojen osalta oman kehysorganisaation strategiset sekä tiedepoliittiset linjaukset ohjaavat kirjastopalveluiden kehittämistä.

Opetushallituksen (2019) julkaisemassa Osaaminen 2035 -raportissa tarkastellaan osaamisalueita, jotka ovat tärkeitä niin työelämä- kuin kansalaistaitoinakin vuonna 2035 . Raportissa esille nousevat taidot ovat pitkälti samoja kuin Hirshillä (2019) ja ALA:n trendikatsauksessa. Vuodelle 2035 ennakoidut uudet osaamiset ovat kirjastolaisille osin jo tätä päivää. Niin asiakastyössä kuin monialaisissa asiantuntijatiimeissä korostuvat vuorovaikutus-, viestintä, ja kommunikaatiotaidot, ongelmanratkaisutaidot sekä itseohjautuvuus.

Tiedonhallintaan liittyvät taidot ovat raportissa vahvasti esillä. Yleisten työelämäosaamisten kymmenen kärjestä löytyvät sekä tiedonhallintaettä analyysitaidot. Tärkeimmäksi kansalaistaidoksi vuonna 2035 raportti nostaa tiedon arviointitaidot. Kymmenen tärkeimmän taidon joukosta löytyvät myös sekä tiedon haku- että hallintataidot. Tärkeimmiksi yleisiksi osaamisalueiksi työelämässä raportissa määritetään asiakaslähtöinen palvelujen kehittämisosaaminen sekä digitaalisten ratkaisujen ja alustojen hyödyntämisosaaminen.

\section{Osaaminen}

korkeakoulukirjastoissa: case Helsingin yliopiston kirjasto

Helsingin yliopisto kirjastossa käynnistettiin vuonna 2018 projekti, jon- 
ka tavoitteena on parantaa henkilöstön osaamisen kehittämisen käytäntöjä. Projektin yhtenä osana on kehitetty työpajamalli, jonka avulla selvitetään, millaisia osaamisia erilaisissa työtehtävissä tarvitaan ja mikä on tarvittava osaamisen taso. Tähän mennessä työpaja on vedetty kirjaston datatukitiimille sekä tiedonhallinnan kouluttajien tiimille.

Edellä mainitut yleiset osaamiset nousivat vahvasti esille myös näissä työpajoissa. Molemmissa tehtävissä työtä tehdään tiiviissä yhteistyössä tutkijoiden, opettajien ja kollegojen kanssa, ja työn vaihtelevuus ja rutiinitehtävien puute korostuvat. Yhteistyö-, viestintä- ja vuorovaikutus- sekä pedagogisten taitojen lisäksi tarvitaan vahvaa itsensä johtamisen/itseohjautuvuuden kykyä. Toisaalta avoimen tieteen tukeminen vaatii tekijöiltään spesifï osaamista esimerkiksi tutkimustyön, tietojärjestelmien ja lainsäädännön osalta. Siis osaamista, joiden haltijat eivät välttämättä löydy perinteisten kirjastoammattilaisten joukosta. Kirjaston viimeaikaisissa rekrytoinneissa hakijoilta onkin toivottu mm. avoimen tieteen, avoimen julkaisemisen tai tutkimusdatan hallinnan toimintatapojen, sekä metriikoiden ja tutkimuksen näkyvyyden edistämisen osaamista hyvien vuorovaikutus-, viestintä- ja neuvontataitojen lisäksi.

\section{Työelämän ja koulutuksen vuoropuhelu}

Korkeakoulukirjastoissa on halua vahvistaa yhteistyötä kirjastoalan kouluttajaorganisaatioiden. Siksi Seinäjoen ammattikorkeakoulun kutsu keskustelemaan kirjastojen osaamistarpeista otettiin vastaan ilolla.

Edellä käsiteltyjä osaamistarpeita tarkasteltaessa on toivottavaa, että koulutuksessa tulisi substanssiosaamisen lisäksi entistäkin paremmin huolehdittua siitä, että opiskelijoille kertyy kokemusta projektimaisesta työskentelytavasta ja tiimityöstä, jossa vuorovaikutus-, ja viestintätaidot pääsevät kehittymään sekä suomeksi että muilla kielillä.

Kirjastoalan opintoihin kuuluu olennaisena osana harjoittelu kaikilla koulutusasteilla. Seinäjoen keskustelussa kirjastoilta toivottiin säännöllistä ja aktiivista harjoittelupaikkojen tarjoamista. Harjoittelupaikat, joissa opiskelijat pääsevät tutustumaan monipuolisesti tieteellisten kirjastojen työtehtäviin ja niiden vaatimuksiin, auttavat opiskelijaa suunnittelemaan opintojaan niin, että ne tukevat hänen tavoitteitaan mahdollisimman hyvin. Harjoittelujen kautta opiskelijat myös vievät kouluttajille ja muille opiskelijoille tietoa työssä tarvittavasta osaamisesta. Se auttaa pitämään vuoropuhelua käynnissä.

Harjoittelujen lisäksi opiskelijoille voidaan kertoa osaamistarpeista myös vierailuluentojen avulla. Seinäjoen elokuisen keskustelun seurauksena asiantuntijat Helsingin yliopiston kirjastosta ovat vierailleet kursseilla kertomassa kansainvälisestä yhteistyöstä sekä avoimen tieteen ja julkaisemisen tehtävistä Helsingin yliopiston kirjastossa. Metropolia Ammattikorkeakoulun kirjastosta on pidetty verkkoluentoja 
opiskelijoille kirjaston kehittämishankkeista. Käytännön esimerkit ihmisten työnkuvista ja siitä työstä mitä kirjastoissa tehdään auttavat opiskelijoita yhdistämään kursseilla saadun teoriatiedon todelliseen työelämään. Tämä toivottavasti innostaa opiskelijoita entistä enemmän tieteellisten kirjastojen tehtävien pariin.

Opintoja suunnitellessa on hyvä tiedostaa, että oppiminen ei pääty oppilaitoksesta valmistumiseen, vaan suuri osa oppimisesta tulee tapahtumaan työpaikalla, työtä tehdessä ja kollegoilta oppimalla. On siis huolehdittava siitä, että valmistuvilla opiskelijoilla on tärkeiden geneeristen osaamisten lisäksi mahdollisimman laaja ymmärrys kirjastojen toimintaympäristöistä ja tehtävistä. Työtehtävien eriytyessä tarvitaan myös kykyä erikoistua johonkin asiantuntijatehtävään ja halu jatkuvaan kehittymiseen läpi työuran.

\section{Mallia maailmalta - täydennyskoulutuksen ongelmat}

$\mathrm{K}$ irjastoalan peruskoulutuksen lisäksi tarvitaan myös täydennyskoulutusta kirjastoissa jo työskenteleville henkilöille. Tieteellisten kirjastojen täydennyskoulutus on tällä hetkellä pitkälti Suomen tieteellisen kirjastoseuran (sTKs) toiminnan varassa. STKs:n työryhmät järjestävät aktiivisesti koulutuspäiviä, joissa painopiste on hyvien käytäntöjen jakamisessa kollegoille. Nopeasti muuttuvassa työympäristössä olisi kuitenkin tarvetta laajemmalle ja systemaattisemmalle täydennyskoulutukselle kuin mitä seu- ra pystyy tarjoamaan.

Mielenkiintoinen esimerkki täydennyskoulutuksen systemaattisesta järjestämisestä löytyy Zagrebista, jossa eri kirjastoalan toimijat ovat tehneet tiivistä yhteistyötä kirjastoammattilaisten osaamisen kehittämiseksi. Vuonna keen tuloksena koulutusohjelma, Training Centre for Continuing Education of Librarians, jota yhteistyössä ylläpitävät Kansallis- ja yliopistokirjasto Zagrebissa, Zagrebin kaupunginkirjastot, Kroatian kirjastoseura, sekä Zagrebin yliopiston Information Sciences -koulutusohjelma. (Filipeti 2019.)

Koulutusohjelma on suunniteltu niin, että se kattaa mahdollisimman laajasti kirjastotyön eri osa-alueet eri kirjastosektoreilla. Kouluttajina toimivat sekä kirjastojen asiantuntijat että yliopiston Information Sciences -koulutusohjelman opettajat. Kouluttajille on tarjottu koulutusohjelman puitteissa myös omaa koulutusta, sekä tilaisuuksia jakaa ryhmässä osaamistaan ja kokemuksiaan. Koulutusta on järjestetty sekä luento-/työpajaopetuksena että webinaareina. Sitä on rahoittanut mm. Kroatian kulttuuriministeriö ja osallistujilta on kerätty pieni osallistumismaksu. (Filipeti 2019.)

Olisiko tämänkaltainen yhteistyö mahdollista myös meillä Suomessa? Vaikka osaamistarpeet hieman poikkeavat eri kirjastosektoreiden välillä, on meillä myös paljon yhteistä. Voisimmeko yhdistää kirjastoseurojen ja kirjastoalan koulutusorganisaatioiden voimat ja saada aikaan systemaattista täydennyskoulutusta? Olisi myös he- 
delmällistä törmäyttää erilaisia näkökulmia kirjastotyöhön yhteisten koulutusten kontekstissa.

\section{Lopuksi}

Korkeakoulukirjastojen rooli tieteellisen tutkimuksen, opetuksen ja oppimisen tukena vaatii kirjastoihin monipuolista osaamista. Kirjastojen on panostettava entistä enemmän kirjastotyön ja palveluiden kriittiseen ja asiakaslähtöiseen kehittämiseen yhteistyössä tutkijoiden, opettajien ja opiskelijoiden sekä muiden tukipalveluiden kanssa. Tulevaisuuden kirjastolaisen on välttämätöntä tuntea asiakkaansa ja toimintaympäristönsä entistä paremmin. Myös kirjastoalan koulutuksen on seurattava työelämässä tapahtuvaa muutosta ja opetussuunnitelmatyöhön on hyvä hyödyntää eri kirjastosektoreiden näkemyksiä. Mielestämme entistä tiiviimpi dialogi työelämän toimijoiden ja kouluttajien välillä ja systemaattinen täydennyskoulutus olisivat avainasemassa tulevaisuuden työelämän haasteisiin vastaamisessa.

\section{Lähteet}

Filipeti, Antonija (2019). Centre for Continuing Education of Librarians in the Republic of Croatia: the Current State and Plans for Further Education. National and University Library in Zagreb.

https://ifla.hkdrustvo.hr/wp-content/uploads/2019/08/Poster-IFLA-

Zagreb-2019-A.-Filipeti.pdf [katsottu I9.I I.2019]

Hirsh, Sandra (2019). Competencies for Librarians in a Technologically-Driven Global Cilmate. Esitys Ruotsin kirjastopäivillä 17.5.2019. https://www.facebook.com/Svbiblioteksfhttps://www.oph.fi/sites/default/ files/documents/osaaminen_2035.pdforening/videos/biblioteksdagarna-2019/ 202484399II45725/ [luettu I.10.2019]

Osaaminen 2035. Osaamisen ennakointifoorumin ensimmäisiä ennakointituloksia. (2019) Opetushallitus, Raportit ja selvitykset 2019:3 https://www.oph.fi/sites/ default/files/documents/osaaminen_2035.pdf [luettu 20.II.20I9]

Trend Collection 2019. Center for the Future of Libraries. American Library Assosioation. http://www.ala.org/tools/future/trends [luettu I I.I0.20I9]

\section{Kirjoittajat}

Hellevi Hakala

tietopalvelupäällikkö

Metropolia Ammattikorkeakoulu hellevi.hakala@metropolia.fi
AnNe KaKKonen

tietoasiantuntija Helsingin yliopiston kirjasto anne.kakkonen@helsinki.fi 